\title{
The Contribution of Reading Motivation in Social Collaboration Dimension to Students' Reading Comprehension
}

\author{
St. Asriati ${ }^{1, *}$, Nur Qalbi ${ }^{1}$, Marwiah $^{2}$, S. Hamsinah ${ }^{3}$ \\ ${ }^{1}$ Department of English Education, Universitas Muhammadiyah, Indonesia \\ ${ }^{2}$ Department of Indonesian Language, Universitas Muhammadiyah, Indonesia \\ ${ }^{3}$ Department of English Education, Institut Parahikma Indonesia, Indonesia
}

Received March 7, 2020; Revised April 2, 2020; Accepted April 19, 2020

Copyright $\bigcirc 2020$ by authors, all rights reserved. Authors agree that this article remains permanently open access under the terms of the Creative Commons Attribution License 4.0 International License

\begin{abstract}
This research aimed to analyze the contribution of reading motivation in social collaboration dimension to students' reading comprehension. Reading motivation is conceptualized as "the individual's goals, values, and beliefs with regard to the topics, processes, and outcomes of reading" (Guthrie \& Wigfield, [15], p. 405). Social Collaboration is one of the dimensions of reading motivation that can support students in reading comprehension. The method of this research was quantitative by applying a random sampling technique (120 samples) from 300 students of Muhammadiyah Makassar University, Indonesia. The data were collected using the questionnaire of Motivation Reading Questionnaire (MRQ), and assessment. The result revealed that there was a positive effect on students' reading motivation toward social collaboration dimension. It also can be indicated that reading motivation contributes to their learning outcome. Social collaboration showed indicator construction with value $0.22^{2}=0.04$. It can also be revealed that reading motivation builds social collaboration dimension which supports or give a positive contribution toward the motivation itself toward the students' reading comprehension
\end{abstract}

Keywords Motivation, Contribution, Reading Comprehension, Reading Motivation

\section{Introduction}

Motivation has long been a major problem for most students of English as a Second Language (ESL) or as a foreign language not only in Indonesia but also elsewhere. It is considered as the most influential factors in learning.
Even students have a vague sense that whether "English will be useful for my future" or not, they do not have a clear idea of what that means, nor is that a very strong motivator; it is too vague and too far off. The first step in tackling the problem of motivation is that the students need to understand and appreciate the role and importance of motivation in any learning. In the context of second language learning Litllewood [19] observes: In second language learning as in every other field of human learning, motivation is the critical force which determines whether a learner embarks on a task at all, how much energy he devotes to it, and how long he perseveres. It is a complex phenomenon and includes many components: the individual's drive, need for achievement and success, curiosity, desire for stimulation and new experience, and so on. A current crisis of schools as stated by Guthrie [14] is student disengagement from literacy.

The well-known relation between achievement and motivation has fueled efforts to increase reading motivation. In describing the Matthew effect, Stanovich [20] stated that reading itself is the greatest contributor to reading development. He further noted the relationship between reading activity and reading development as follows: The effect of reading volume on vocabulary growth, combined with the large skill differences in reading volume, could mean that a "rich-get-richer" or cumulative advantage phenomenon is almost inextricably embedded within the developmental course of reading progress. The very children who are reading well and who have good vocabularies will read more, learn more word meanings, and hence read even better. (p 381). Stanovich's [20] assertion has been supported through theoretical arguments and empirical research (Anderson et al., [2]; Anderson et al., [3]; Cunningham \& Stanovich, [5]; Guthrie [12]; Guthrie et al., [15]; Guthrie \& Wigfield, [8]; 
Guthrie et al., [9]. Since reading activity is the greatest contributor of reading comprehension and achievement, it stands to reason that increasing the amount that children read is a top priority in reading instruction. Increasing children reading activity; however, is not a simple task. Reading is a motivated act Guthrie \& Wigfield, [11], an effortful activity in which individuals have a choice about engaging, Guthrie \& Wigfield, [9]. The pattern of interaction that is present between reading activity and reading achievement is also apparent between reading motivation and reading activity. There is sample evidence in the literature of the correlation between reading motivation and reading activity, Baker \& Wigfield, [6]; Guthrie et al., [11]; Wigfield \& Guthrie, [13] Children's reading motivation is a significant predictor of reading activity. Students who report higher reading motivation also report engaging in reading with more frequency than those who report lower reading motivation. Guthrie and Wigfield [14] offered evidence that "Reading motivation predicts children's amount of reading, which, in turn, predicts reading comprehension" Guthrie et al., [12]. While the relations between reading activity and reading achievement; and between reading motivation and reading activity are clear and direct, the relationship between reading motivation and reading achievement is more complex. Furthermore, there are a limited number of studies investigating the relationship between reading motivation and reading achievement. Guthrie and Klauda [12] found that reading motivation was both antecedent and predictive of reading amount. "These conditions of antecedence and prediction are usually suggestive of a causal direction" Guthrie et al., [11]. Guthrie and Wigfield [14] suggested that reading motivation mediates the Matthew effect: "Increasing competence is motivating and increasing motivation leads to more reading.

Motivation is the link between frequent reading and reading achievement. This link sustains the upward (and downward) spiral of achievement" (p. 405). This link between reading motivation and reading activity is central to understanding the role of motivation in reading comprehension and achievement, Guthrie et al., [12]. Motivation is a process rather than a product. As a process that does not observe motivation directly but rather infer it from actions (e.g., choice of tasks, effort, persistence) and verbalizations (e.g., "I really want to work on this"). Motivation involves goals that provide the impetus for and direction to action. Cognitive views of motivation are united in their emphasis on the importance of goals. Goals may not be well formulated and may change with experience, but the point is that individuals are conscious of something that they are trying to attain or avoid. Motivation requires activity-physical or mental. The physical activity entails effort, persistence, and other overt actions. The mental activity includes such cognitive actions as planning, rehearsing, organizing, monitoring, making decisions, solving problems, and assessing progress. Most activities that students engage in are geared toward attaining their goals Dornyei [12].

Research has demonstrated that there are different dimensions of reading motivation (Baker \& Wigfield, [6]; Wigfield \& Guthrie, [30]; Wigfield et al, [31], and instructional practices that foster those dimensions have enhancing effects on both reading motivation and reading comprehension Wigfield et al., [32]. Interventions aimed at increasing reading motivation have included the provision of choice and autonomy support, use of interesting texts, collaboration for learning, and content goals for instruction Guthrie et al., [16].

\section{Literature Review}

\subsection{Social Collaboration}

Social collaboration during reading, that includes social goals and collaborative activities, was the fourth motivation-supporting practice. Mean effect sizes for collaboration were 0.52 for motivation, and 0.48 for text comprehension. Motivation-supporting practices appear to increase motivation and text comprehension in controlled laboratory-based studies Reynolds \& Symons [27]. Collaboration among learners in reading is been correlated with dimensions of intrinsic motivation such as curiosity and reading involvement, as well as amount and breadth of reading Wigfield \&Guthrie [33]. Students who like to participate in a group of learners by completing assignment are likely intrinsically motivated readers and subsequently have more positive reading outcomes. Social motivation also leads to more reading, more effort, and greater levels of achievement in reading. Collaboration among learners in reading is been correlated with dimensions of intrinsic motivation such as curiosity and reading involvement, as well as amount and breadth of reading Wigfield \& Guthrie [33]. Students who like to participate in a group of learners by completing the assignment are likely intrinsically motivated readers and subsequently have more positive reading outcomes. Social motivation also leads to more reading, more effort, and greater levels of achievement in reading. $f$

Students' intrinsic motivation and efficacy during their work with complex comprehension strategies are increased when they have opportunities to share their questions, interesting texts, and new information Gambrell, Mazzoni, \& Almasi, [12]. Systematic support for collaborative activity enables students to clarify their understanding of the core ecological concepts. Students greatly enjoy working with other students, and when such groups are structured in productive ways, students' motivation and learning can be enhanced.

\subsection{Reading Motivation}

Achievement motivation and motivation in specific 
domains such as reading are construed as multidimensional phenomena (e.g., Eccles \& Wigfield [15]; Schiefele [26]; Wang \& Guthrie [31]; Wigfield \& Guthrie [32]. Factor analysis has distinguished at least nine components of reading motivation (Baker \& Wigfield [6]; Wigfield \& Guthrie, [32]: (a) interest, (b) preference for challenge, (c) involvement, (d) self-efficacy, (e) competition, (f) recognition, (g) grades, (h) social interaction, and (i) work avoidance.

Furthermore, motivations that are more internal, such as interest or curiosity, preference for challenge, and involvement have been distinguished as separate construct in structural equation modeling from more external motivations such as grades and recognition and have been found to be strongly associated with reading comprehension not only in Caucasion students, but also in minority students and other cultures (Unrau \& Schackman, [29]; Wang; \& Guthrie, [32]. Reading Comprehension is one of the most essential study skills in higher education. Academic and even technical courses demand substantial readings, so there is a need for students to be able to comprehend what they read in order to succeed in their academic life and beyond. Reading comprehension is one of the most essential skills that should be developed and nurtured in a child at home and in school because it is fundamental to success in academic life and beyond. According to Al Noursi [2], the ability to read for various purposes is a precursor of a successful learning in schools, colleges, and universities. He further notes that it is a survival skill in the 21 st century may it be for students or professionals. Hasselbring [22], p. 1), on the other hand, consider reading as 'the key enabler of learning for academic proficiency'.

Hence, not being able to develop effective reading can have adverse effects on learning across the curriculum, motivation to read, attitudes toward life, and performances in the workplace. Reading, which is one of the four language skills, can be classified into two types: initial reading and reading comprehension.

The teaching of reading as a foreign language (EFL reading) in Indonesia can be generally included in the teaching of reading comprehension. This is because it aims to improve the skills of learners, who have been able to read in their first language and in EFL, in understanding the meaning of a written text.

\section{Methodology}

This research was quantitative in nature that use path analysis. Garson [14] A path analysis design is used to see the model of the relationship between the variables. It also used Structural Equation Model (SEM) in analysis of Moment Structure (AMOS), that is the influence of motivation toward reading comprehension. This study used two kinds instruments, namely questionnaire and reading test. First one, the questionnaire was aimed to measure the students' motivation in reading using The Motivation Reading Questionnaire (MRQ) that consisted of 20 items. The Likert Scale was arranged in four level (1-4 level). The statements were categorized as negative and positive statement. Positive statement with the answer A Lot Like Me (4), A Little Like Me ((3), A Little Different from Me (2), Very Different from Me (1). Negative statement with score the opposite of positive statement. Before distributing the set of each questionnaire to the sample of study, each of them was piloted to a group of students who were purposively separated from the sample. Due to the limited number of students who were selected as the sample and in order to fulfill the minimum requirement of sampling in the path analysis, the students participating in this pilot study were chosen from different class. There were 120 students from the Faculty of teacher training and education majoring English in the fourth semester. It was assumed these students have similar characteristics of the sample group and would be able to help in validating the instrument. It was estimated that each questionnaire needs estimated time of around 30 to 60 minutes. The piloting process was conducted in order to test the validity of the questionnaire content; whether the wording is clear and understood by the respondents. In addition to find out the validity of the questionnaire, the piloting process also looked for the reliability. The second was Reading test to know the students' achievement in reading that focuses on detail, sequence, inference, vocabulary, and main idea. It also conducted piloting as the same as questionnaire. The question of reading assessment consisted of 20 numbers of items but after piloting just consisted of 15 questions. Test-retest is a method that administers the same instrument to the same sample at two different points in time, perhaps one year intervals. If the scores at both time periods are highly correlated, $>.60$, they can be considered reliable. The alternative form method requires two different instruments consisting of similar content. The same sample must take both instruments and the scores from both instruments must be correlated. If the correlations are high, the instrument is considered reliable. Internal consistency uses one instrument administered only once. The coefficient alpha (or Cronbach's alpha) is used to assess the internal consistency of the item. If the alpha value is .70 or higher, the instrument is considered reliable.

\begin{tabular}{|c|c|}
\hline \multicolumn{2}{|c|}{ Reliability Statistics } \\
\hline Cronbach's Alpha & N of Items \\
\hline .661 & 20 \\
\hline
\end{tabular}

\section{Finding}

\subsection{Reading Motivation in Social Collaboration Dimension}

The descriptive statistics of students reading motivation that consists of social collaboration have mean score 10.28 
from 120 respondent of Universitas Muhammadiyah Makassar, Indonesia, the fourth semester. Looking at the minimum and maximum score of the students, it seems that those scores are seen as the two extremes (very low and very high).

Table 1. Descriptive statistics of dimension on reading motivation

\begin{tabular}{|c|c|c|c|c|c|}
\hline Variable & $\mathrm{N}$ & Minimum & Maximum & Mean & $\begin{array}{c}\text { Std. } \\
\text { Deviation }\end{array}$ \\
\hline $\begin{array}{c}\text { Social } \\
\text { collaboration }\end{array}$ & 120 & 8 & 12 & 10.28 & .952 \\
\hline $\begin{array}{c}\text { Valid N } \\
\text { (listwise) }\end{array}$ & 120 & & & & \\
\hline
\end{tabular}

Descriptive and Inferential Statistics on Social Collaboration Dimension of Reading Motivation

As shown in the table 2. The percentage of the students' social collaboration in good and excellent levels were $56.7 \%$ and $43.3 \%$, respectively. Therefore, majority of the students were in good level. The good level occupied students' social collaboration occupied the first position while excellent level was found in the second position. None of students was classified poor and fair. It can be stated that their social collaboration was good. In order to have clearer description on students' social collaboration level it can be seen from the figure 1 and also the description of Reading Comprehension has been broken down into the detail, sequence, inference, vocabulary, and main idea can be seen in the figure 2 .

Table 2. Students' Social Collaboration Description

\begin{tabular}{|c|c|c|c|}
\hline Interval & Classification & Total & Percentage \\
\hline $3-4.5$ & Poor & 0 & 0 \\
\hline $4.6-7.6$ & Fair & 0 & 0 \\
\hline $7.6-10.5$ & Good & 68 & 56.7 \\
\hline $10.6-12$ & Excellent & 52 & 43.3 \\
\hline
\end{tabular}

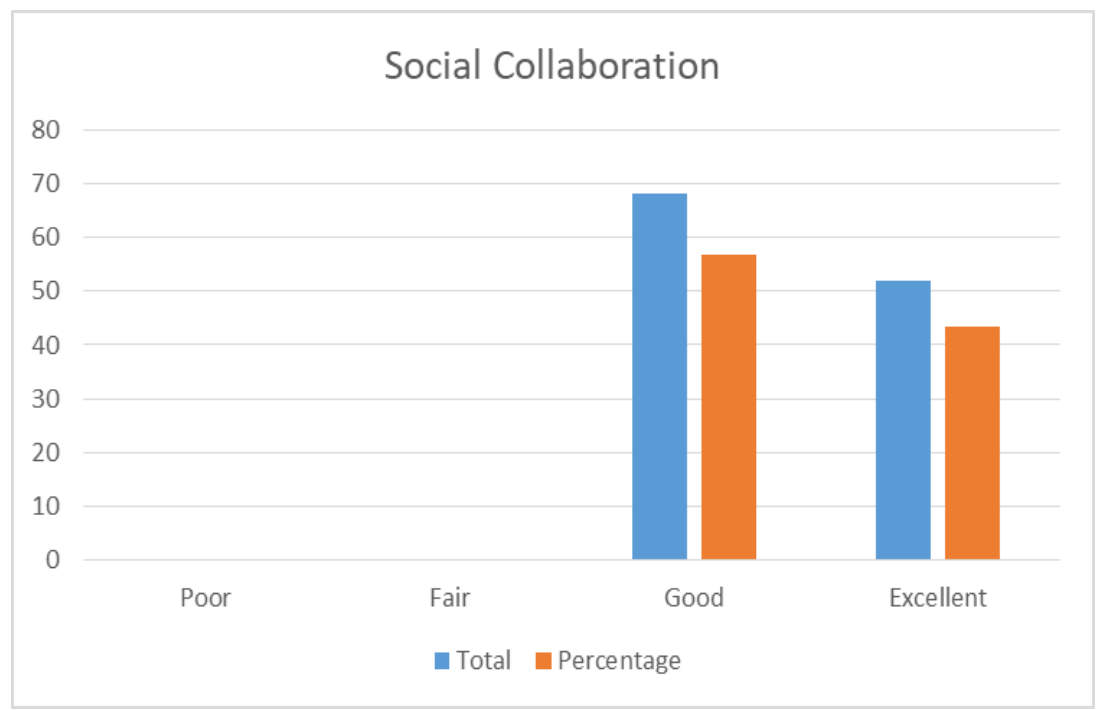

Figure 1. The percentage of students' social collaboration

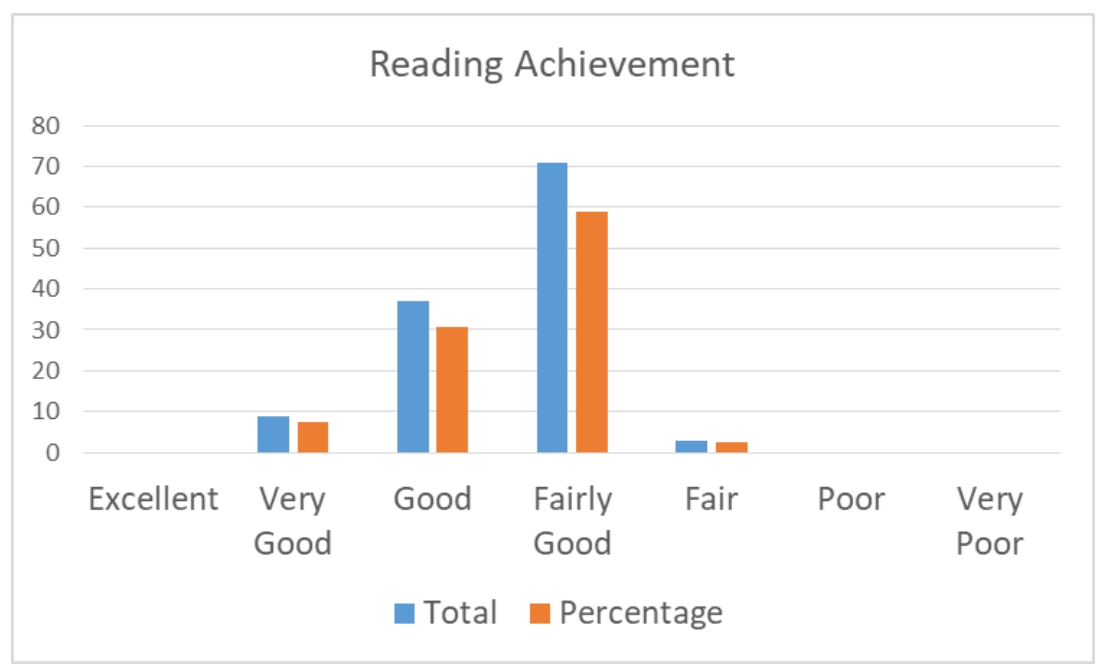

Figure 2. The percentage of Reading Achievement 


\subsection{Students' Reading Comprehension}

Therefore, to achieve explanation about the descriptive statistic of Students' Reading Comprehension. It can be seen from the following table.

Table 3. Descriptive statistics of Students' Reading Comprehension

\begin{tabular}{|c|c|c|c|c|c|}
\hline Indicator & $\mathrm{N}$ & Minimum & Maximum & Mean & $\begin{array}{c}\text { Std. } \\
\text { Deviation }\end{array}$ \\
\hline detail & 120 & 10 & 36 & 18.80 & 5.849 \\
\hline sequent & 120 & 10 & 37 & 21.67 & 5.730 \\
\hline inference & 120 & 14 & 36 & 24.29 & 4.884 \\
\hline vocab & 120 & 16 & 39 & 27.02 & 4.466 \\
\hline main & 120 & 10 & 36 & 21.30 & 6.373 \\
\hline $\begin{array}{c}\text { Valid N } \\
\text { (listwise) }\end{array}$ & 120 & & & & \\
\hline
\end{tabular}

As shown in above table. 3 the mean score of students' vocabulary was 27.02 (the highest), and students' detail mean score was 18.80 (the lowest). From this result, it is assumed that the students had high achievement in vocabulary. Meanwhile, the mean score of the other indicator of reading achievement were ranging from 21.30 (main idea) 21.67 (sequent), and 24.29 (inference). Looking at the minimum and maximum score of the students on each variable, it seems that those scores are seen as the two extremes (very low and very high).

\subsection{Path Design}

Figure 3 showed that there was positive influence motivation toward reading which every improvement motivation caused the improvement of reading achievement 5.97. Students who have motivated were able to improve their achievement in reading. In particular, students with high motivation reported high reading achievement.

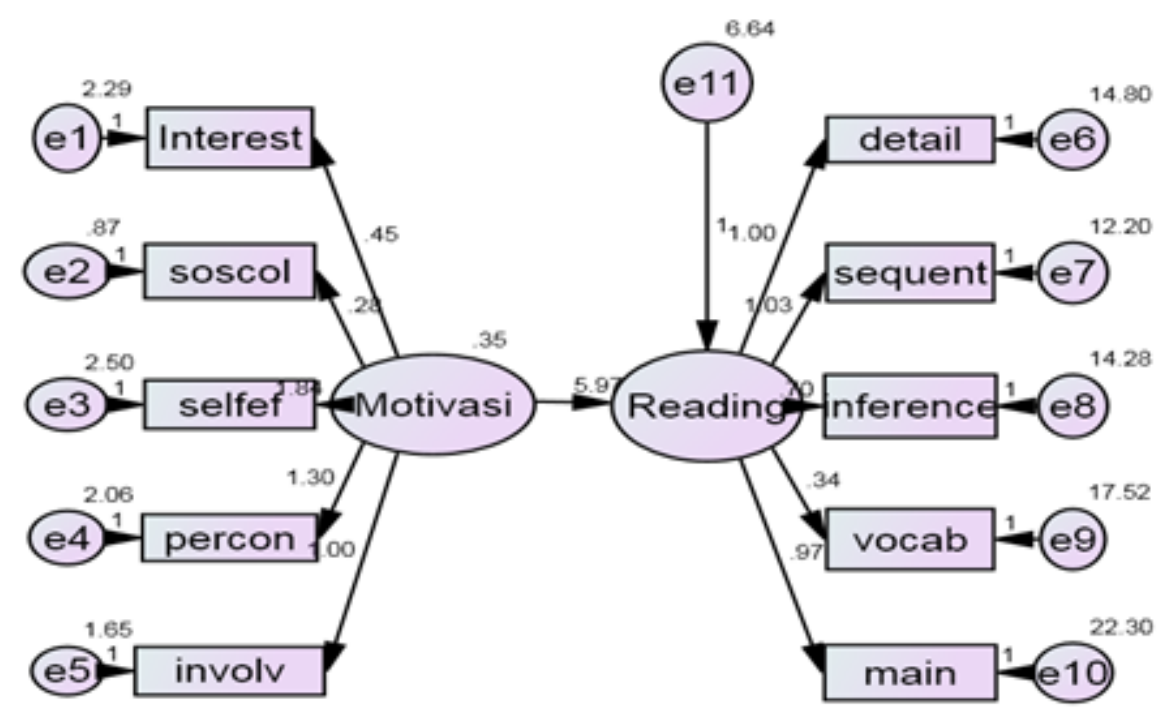

Figure 3. Path Design 


\section{Discussion}

Nejad and Keshavarsi A (2015) state that there is correlation between social collaboration and reading. He further noted that control group was more anxious in reading than experimental group. In the case of students' attitudes, the average mean of attitude score for students in the cooperative learning group showed a strong relationship with this learning approach. $n$

This study supports that cooperative learning is a good option in teaching reading comprehension and can work better than traditional direct instruction in improving the reading comprehension achievement of students. So, it is beneficial for teachers to develop reading comprehension knowledge, small group cooperative skills, and abilities of students in accordance with the academic requirements.

Applying cooperative learning in the classroom does not mean abandoning the teacher-fronted mode, but it emphasizes various modes of learning. Therefor to achieve this goal, it is essential to train teachers to know how to participate students in learning process, how and when to assign learning objectives to learners and how to monitor each student within each small group.

The findings of the study also proved the results of Johnson and Johnson (1995) who believe that if group mates feel positively interdependent with one another, a supportive atmosphere can develop their learning too. The use of cooperative learning in reading comprehension classes can lead to students' reading anxiety reduction and higher performance in reading comprehension.

\section{Conclusions}

The impartial of this study was targeted to justify reading motivation in social collaboration dimension subsidizes to the students' reading comprehension. Based on findings and discussion, it is decided that students who develop good assessment in reading also take good social collaboration dimension. It is confirmed from reading motivation in social collaboration dimension and reading comprehension devise a positive connection. Social collaboration implied low indicator construction with value $0.22^{2}=0.04$. It also can be shown that reading motivation is constructed social collaboration which cares or contribute a positive contribution toward the motivation itself toward the students' reading comprehension.

\section{Acknowledgments}

My most profound and sincere appreciation goes to Universitas Muhammadiyah Makassar, Indonesia. I am also indebted thanks to the second semester students of English Education Department 2018/2019 academic years at Muhammadiyah University Makassar who have given their serious attention and active participation as the subjects of the research.

\section{Appendix 1. The Questionnaire Items}

\begin{tabular}{|l|l|l|l|l|l|}
\hline No. & Motivation for Reading Questionnaire & \multicolumn{4}{|c|}{ scoring } \\
\hline 1. & $\begin{array}{l}\text { I find reading comprehension useful to me } \\
\text { in my daily life }\end{array}$ & 1 & 2 & 3 & 4 \\
\hline 2. & $\begin{array}{l}\text { I study reading comprehension course to } \\
\text { get a better job in the future }\end{array}$ & 1 & 2 & 3 & 4 \\
\hline 3. & $\begin{array}{l}\text { Reading subject has content that covers } \\
\text { many fields of knowledge }\end{array}$ & 1 & 2 & 3 & 4 \\
\hline 4. & I like hearing the teacher's reading & 1 & 2 & 3 & 4 \\
\hline 5. & $\begin{array}{l}\text { I only learn English when I have to revise } \\
\text { for test }\end{array}$ & 1 & 2 & 3 & 4 \\
\hline 6. & $\begin{array}{l}\text { If the teacher discusses something } \\
\text { interesting, I might read more about it. }\end{array}$ & 1 & 2 & 3 & 4 \\
\hline 7. & $\begin{array}{l}\text { My friends sometimes tell me I am a good } \\
\text { reader. }\end{array}$ & 1 & 2 & 3 & 4 \\
\hline
\end{tabular}

\section{Appendix 2. Reading Assessment}

The inventory with questions

The Astonishing Adventures of Patrick the Mouse

Have you ever solved a mystery by accident? Read to find out what mystery Patrick the mouse solves.

It was quite late, so Patrick was all by himself on deck. He had been standing awhile and looking up at the dark sky, where the stars were shining like millions of flashlights, when he suddenly heard whispering voices close by.

He became curious and sneaked closer. Now he could hear the voices quite plainly. They came from a lifeboat close by, and when Patrick cautiously stretched his head out behind boat, he saw, in the faint moonlight, two fat ship's rats sitting and whispering together.

"Quite a take for one day, Charlie!"

"I'll say it was, jack. We'll get a pile of dough for that one when we sell it in New York. Ho, ho, ho!"

"Aha, the necklace thieves!" Patrick said to himself. “Too bad Mr. Dupont isn't here. I can't catch both of them all by myself, and if I go for help, they may have time to get away before I get back!"

"Tomorrow, we'll try number 34," said Jack. "The old lady who has that cabin keeps a big box of jewelry under her pillow. While everyone's at lunch, we'll gnaw a hole in the box and take along as much as we can carry."

\section{Questions}

Direction: Please answer in complete sentences.

1) What did Patrick notice about the dark sky?

2) What happened that made Patrick curious?

3) What was the secret the rats were whispering about in the lifeboat? 
4) In this story what does "plainly" mean?

5) In this story what does "get away" mean?

6) What is the mood of the rats?

7) Why did Patrick think the rats were the necklace thieves?

8) Why would the rats wait for everyone to go to lunch?

9) What is the problem Patrick faces?

10) What do you think Patrick will do next?

\section{REFERENCES}

[1] Almasi, J. F. (1995). The nature of fourth graders' sociocognitive conflicts in peer-led and teacher-led discussions of literature. Reading Research Quarterly, 314-351.

[2] Al Noursi, O. H. (2014). To read or not to read. Focusing on EFL reading, 241-269.

[3] Anderson, R. C., Hiebert, E., Scott, J. A., \& Wilkinson, A. G. (1985). Becoming a nation of readers: The report of the commission on reading. Washington, DC: National Institute of Education.

[4] Anderson, R. C., Wilson, P. T., \& Fielding, L. G. (1988). Growth in reading and how children spend time outside of school. Reading Research

[5] Anderson, R. C., Wilson, P. T., \& Fielding, L. G. (1988). Growth in reading and how children spend their time outside of school. Reading Research Quarterly 23, 285-303.

[6] A. Abiewskiro,. Z. Moplskiiera. The Problem of Grammar Choice for Verification, TCSET of the International Conference, House of Lviv Polytechnic National University, 19-23, 2008.

[7] Baker, L., \& Wigfield, A. (1999). Dimensions of children's motivation for reading and their relations to reading activity and reading achievement. Reading research quarterly, 34(4), $452-477$.

[8] Cunningham, A., \& Stanovich, K., E. (2003). Reading can make you smarter! Principal, 83(2), 34-39.

[9] Cunningham, A. E., \& Stanovich, K. E. (2003). Reading matters: How reading engagement influences cognition. Handbook of research on teaching the English language arts, 2, 857-867.

[10] Dörnyei, Z. (2001). Motivation strategies in the language classroom. Ernst Klett Sprachen

[11] Eccles, J. S., \& Wigfield, A. (2002). Motivational beliefs, values, and goals. Annual review of psychology, 53(1), 109-132.

[12] Farquhar C, Protein and DNA Music, Online available from http://www.hrpub.org

[13] Gambrell, L. B., Mazzoni, S. A., \& Almasi, J. F. (2000). Promoting collaboration, social interaction, and engagement with text. Engaging young readers: Promoting achievement and motivation, 119-139.
[14] Garson, G. D. (2013). Path analysis. Asheboro, NC: Statistical Associates Publishing.

[15] Guthrie, J. T., Wigfield, A., Metsala, J. L., \& Cox, K. E. (1999). Motivational and cognitive predictors of text comprehension and reading amount. Scientific studies of reading, 3(3), 231-256.

[16] Guthrie, J. T., \& Wigfield, A. (1999). How motivation fits into a science of reading. Scientific Studies of reading, 3, 199-205.

[17] Guthrie, J. T., McGough, K., \& Wigfield, A. (1994). Measuring reading activity: An inventory. (Instructional Resource No. 4). Athens GA: National Reading Research Center.

[18] Guthrie, J. T., Wigfield, A., \& VonSecker, C. (2000). Effects of integrated instruction on motivation and strategy use in reading. Journal of Educational

[19] Guthrie, J. T., Wigfield, A., Barbosa, P., Perencevich, K. C., Taboada, A., Davis, M. H., ... \& Tonks, S. (2004). Increasing reading comprehension and engagement through concept-oriented reading instruction. Journal of educational psychology, 96(3), 403.

[20] Guthrie, J. T., McRae, A., \& Klauda, S. L. (2007). Contributions of concept-oriented reading instruction to knowledge about interventions for motivations in reading. Educational Psychologist, 42(4), 237-250.

[21] Guthrie, J. T. (2004). Teaching for literacy engagement. Journal of Literacy Research, 36, 1-29.

[22] Guthrie, J. T., Schafer, W. D., \& Huang, C. (2001). Benefits of opportunity to read and balanced instruction on the NAEP. The Journal of Educational

[23] Hasselbring, T. S. (2007). What we know about adolescent reading.

[24] Johnston, P. H. (1983). Reading comprehension assessment: A cognitive basis. International Reading Association, 800 Barksdale Rd., PO Box 8139, Newark, DE 19711 (Order No. 951, \$4.50 member, $\$ 6.50$ non-member).

[25] Johnston, C., \& Orwig, C. (1999). Your learning style and language learning. Lingua Links Library.

[26] Nejad, S. G., \& Keshavarzi, A. (2015). The Effect of Cooperative Learning on Reading Comprehension and Reading Anxiety of Pre-University Students. Journal of Applied Linguistics and Language Research, 2(8), 169-180.

[27] Littlewood, W. (2004). The task-based approach: Some questions and suggestions. ELT journal, 58(4), 319-326.

[28] Stanovich, K. E., \& Cunningham, A. E. (1992). Studying the consequences of literacy within a literate society: The cognitive correlates of print exposure. Memory \& Cognition, 20, 50-68.

[29] Schiefele, U. (1999). Interest and learning from text. Scientific studies of reading, 3(3), 257-279.

[30] R. F. Voss, J. Clarke. Algorithmic Musical Composition, Silver Burdett Press, Londyn, 1986.

[31] Reynolds, P. L., \& Symons, S. (2001). Motivational variables and children's text search. Journal of Educational 
Psychology, 93(1), 14.

[32] Unrau, N., \& Schlackman, J. (2006). Motivation and its relationship with reading achievement in an urban middle school. The Journal of Educational Research, 100(2), 81-101.

[33] W. Zabierowski, A. Napieralski. Chords classification in tonal music, Journal of Environment Studies, Vol.10, No.5, 50-53.

[34] Wang, J. H. Y., \& Guthrie, J. T. (2004). Modeling the effects of intrinsic motivation, extrinsic motivation, amount of reading, and past reading achievement on text comprehension between US and Chinese students. Reading Research Quarterly, 39(2), 162-186.

[35] Wigfield, A., \& Guthrie, J. T. (1997). Relations of children's motivation for reading to the amount and breadth or their reading. Journal of educational psychology, 89(3), 420.

[36] Wigfield, A., Guthrie, J. T., \& McGough, K. (1996). A questionnaire measure of children' $s$ motivations for reading (Instructional Resource No. 22). Athens, GA: National Reading Research Center, Universities of Georgia and Maryland.

[37] Wigfield, A., Guthrie, J. T., Tonks, S., \& Perencevich, K. C. (2004). Children's motivation for reading: Domain specificity and instructional influences. The Journal of Educational Research, 97, 299-309. 